\title{
PERAN TENTARA NASIONAL INDONESIA DALAM PEMBERANTASAN TERORISME DALAM UPAYA MENJAGA KEDAULATAN NEGARA KESATUAN REPUBLIK INDONESIA DITINJAU DARI PERSPEKTIF PEMBAHARUAN HUKUM PIDANA
}

\author{
Kriswanto \\ Program Studi Doktor Ilmu Hukum \\ Pascasarjana Universitas Islam Bandung \\ e-mail: kriswanto.kayat@gmail.com
}

\begin{abstract}
Abstrak : Salah satu tujuan pembentukan suatu negara adalah untuk melindungi warga negara. Oleh karena itu, mewujudkan pertahanan dan keamanan merupakan elemen yang melekat dalam tujuan penyelenggaraan negara. Pada saat ini fenomena terorisme telah menjadi fenomena global yang telah merambah seluruh negara termasuk Indonesia. Terorisme merupakan extra ordinary crime karena telah membahayakan idiologi, keamanan, kedaulatan dan mempunyai tujuan tertentu. Dibutuhkan penanganan secara khusus, terarah, terencana dan berkesinambungan dari seluruh komponen negara termasuk dalam melibatkan TNI untuk memberantas tindak pidana terorisme dan dibutuhkan kerjasama antar lembagalembaga terkait serta seluruh komponen masyarakat termasuk TNI. Penelitian ini bertujuan untuk memahami kebijakan formulasi peran TNI dalam pemberantasan terorisme dalam upaya menjaga kedaulatan NKRI ditinjau dari perspektif pembaharuan hukum pidana, implementasi peran TNI dalam pemberantasan terorisme dalam upaya menjaga kedaulatan NKRI ditinjau dari perspektif pembaharuan hukum pidana serta peran TNI dalam pemberantasan terorisme dimasa yang akan datang dalam upaya menjaga kedaulatan NKRI ditinjau dari perspektif pembaharuan hukum pidana. Metode Pendekatan yang digunakan dalam penelitian ini adalah pendekatan yuridis normatif. Peran tentara nasional Indonesia dalam pemberantasan terorisme dalam upaya menjaga kedaulatan negara kesatuan Republik Indonesia ditinjau dari perspektif pembaharuan hukum pidana dapat dilihat dalam beberapa tahap, yakni melalui tahap kebijakan formulasi, tahap implementasi dan peran TNI dimasa yang akan datang.
\end{abstract}

Kata Kunci: Tentara Nasional Indonesia, Terorisme, Pembaharuan Hukum Pidana

\begin{abstract}
One of the goals of forming a country is to protect citizens. Therefore, creating defense and security is an element that is inherent in the objectives of state administration. At this time the phenomenon of terrorism has become a global phenomenon that has penetrated all countries including Indonesia. Terrorism is an extraordinary crime because it has endangered the ideology, security, sovereignty and has a certain purpose. Special handling, directed, planned and continuous handling of all components of the country is needed including involving the TNI to eradicate terrorism and requires cooperation between relevant institutions and all components of society including the TNI. This study aims to understand the policy formulation of the role of the TNI in eradicating terrorism. in an effort to safeguard the sovereignty of the Republic of Indonesia from the perspective of criminal law renewal, the implementation of the role of the TNI in eradicating terrorism in terms of NKRI reformation and the role of the TNI in eradicating terrorism in the future in an effort to safeguard NKRI sovereignty in terms of criminal law renewal perspective. Method The
\end{abstract}


approach used in this study is a normative juridical approach. The role of the Indonesian national army in eradicating terrorism in an effort to safeguard the sovereignty of the unitary state of the Republic of Indonesia in terms of reforming criminal law can be seen in several stages, namely through the formulation policy stage, the implementation stage and the role of the TNI in the future.

Keywords: Indonesian National Army, Terrorism, Criminal Law Reform

\section{A. PENDAHULUAN}

Negara adalah suatu organisasi yang memiliki tujuan. Pada konteks negara Indonesia, tujuan negara tertuang dalam alinea keempat Pembukaan UndangUndang Dasar 1945 yang mengidentifikasikan bahwa Indonesia merupakan negara hukum yang menganut konsep welfare state (negara kesejahteraan). Sebagai negara hukum yang bertujuan mewujudkan kesejahteraan umum, setiap kegiatan di samping harus diorientasikan pada tujuan yang hendak dicapai juga harus berdasarkan pada hukum yang berlaku sebagai aturan kegiatan kenegaraan, pemerintahan, dan kemasyarakatan. ${ }^{1}$

Apabila melihat peristiwa terorisme yang telah terjadi di Indonesia, tindak pidana terorisme tersebut berdampak terhadap gangguan keamanan negara yang merupakan tugas pokok dan fungsi Tentara Nasional Indonesia untuk menjaga keamanan negara. Sehingga harus

\footnotetext{
${ }^{1}$ Juniarso Ridwan, Achmad Sodik Sudrajat, Hukum Administrasi Negara Dan Kebijakan Layanan Publik, Nuansa Cendekia, Bandung, 2014, Hlm. 11
}

dipahami, bahwa pelibatan TNI dalam pemberantasan tindak pidana terorisme bukan dalam ranah penegakan hukum. ${ }^{2}$

Tabel 1.1 Data Kasus Terorisme Di Indonesia Dari Tahun 2015-2018

\begin{tabular}{|c|c|c|c|}
\hline TAHUN & $\begin{array}{c}\text { JUMLAH } \\
\text { KASUS }\end{array}$ & $\begin{array}{c}\text { JUMLAH } \\
\text { TERSANGKA }\end{array}$ & $\begin{array}{c}\text { JUMLAH } \\
\text { TEROR } \\
\text { BOM }\end{array}$ \\
\hline 2015 & 4 & 15 & 0 \\
\hline 2016 & 5 & 12 & 2 \\
\hline 2017 & 8 & 17 & 2 \\
\hline 2018 & 22 & 43 & 5 \\
\hline TOTAL & $\mathbf{3 9}$ & $\mathbf{8 7}$ & $\mathbf{9}$ \\
\hline Sumber: Badan
\end{tabular}

Terorisme (BNPT) Tahun 2018.

Berdasarkan tabel di atas, terjadi peningkatan jumlah kasus tindak pidana terorisme yang terjadi di Indonesia dari tahun 2015 sampai dengan tahun 2018. Peningkatan terbesar terjadi pada tahun 2018 yaitu sebanyak 22 kasus dengan jumlah tersangka sebanyak 43 orang. Begitu juga terjadi peningkatan jumlah kasus terror bom di Indonesia dari tahun 2015 sampai dengan tahun 2018. Peningkatan terbesar terjadi pada tahun 2018, yaitu sebanyak 5 kasus.

\footnotetext{
2 Edy Imran, Pelibatan TNI Dalam Pemberantasan Aksi Terorisme, Seminar, Universitas Indonesia, 2018, Hlm. 8
} 


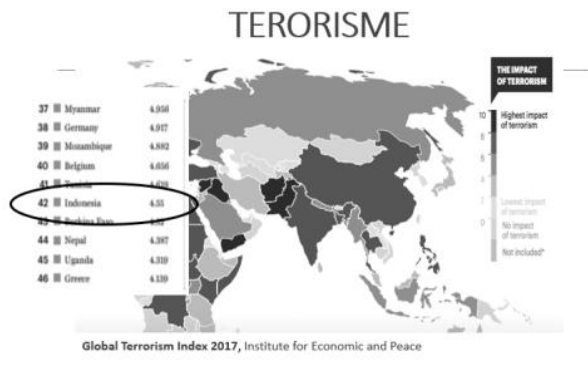

Gambar 1.1 Data Aksi Terorisme Sedunia Dari Lembaga Ekonomi Dan Perdamaian (Institute For Economic And Peace)

Berdasarkan tabel tersebut diatas Indonesia menempati urutan ke-42 ancaman aksi terorisme dari hampir 200 lebih negara di dunia. Ini artinya aksi terorisme di Indonesia sudah masuk dalam level yang sangat kritis untuk ancaman terhadap kedaulatan dan keselamatan sebuah bangsa dan negara, untuk itu pelibatan Tentara Nasional Indonesia sudah sangat dibutuhkan.

Menurut Abdul Fickar, pelibatan TNI dalam pemberantasan terorisme merupakan sebuah hal yang dimungkinkan bila terorisme dilihat sebagai sebuah tindakan yang mengancam keutuhan dan pertahanan negara. Namun, operasi dalam pemberantasan terorisme yang melibatkan TNI harus didahului dan didasarkan pada perintah Presiden.

Negara hukum Indonesia menerima prinsip kepastian di dalam rechtstaat, demikian pula prinsip rasa keadilan di dalam the rule of law serta nilai spiritual dari hukum agama. Hukum tertulis dengan segala prosedural yang demikian itu semuanya harus diletakkan dalam konteks penegakan keadilan. ${ }^{3}$

Indonesia sebagai negara hukum yang demokratis, maka kekuasaan dari organ-organ negara dan/atau lembaga negara manapun di republik ini harus berlandaskan konstitusi yang bertujuan agar para penyelenggara negara tidak parsial dan mempunyai arah serta tujuan yang jelas dalam menjalankan tugas dan kewenangannya. ${ }^{4}$

Politik hukum memerlukan sebuah mekanisme yang melibatkan banyak faktor. Dari pengertian ini, politik hukum mempunyai dua ruang lingkup yang saling terkait, yaitu dimensi filosofis-teoritis dan dimensi normatif-operasional. Sebagai dimensi filosofis-teoritis, politik hukum merupakan parameter nilai bagi implementasi pembangunan dan pembinaan hukum di lapangan. Sebagai dimensi normatif operasional, politik

Mahfud M.D. (1), Perdebatan Hukum Tata Negara Pasca Amandemen Konstitusi, LP3ES, Jakarta, 2007, Hlm. 51

4 Yusril Ihza Mahendra, Dinamika Tata Negara Indonesia: Konfilasi Aktual Masalah Konstitusi Dewan Perwakilan dan Sistem Kepartaian, Gema Insani, Jakarta, 1996, Hlm. 46 
hukum lebih terfokus pada pencerminan kehendak penguasa terhadap tatanan masyarakat yang diinginkan. ${ }^{5}$

Upaya penanggulangan kejahatan tidak dapat diselesaikan hanya dengan hukum pidana saja, tetapi memerlukan sarana lain yang bersifat non-penal, yaitu hukum administrasi, hukum perdata dan upaya-upaya non-penal lainnya yang lebih luas untuk menghilangkan kondisi-kondisi secara langsung atau tidak langsung yang dapat menimbulkan kejahatan kriminogen maupun viktimogen. Lebih jauh Hoefnagels menyatakan masalah utama dari kejahatan dan pemidanaan tidak berada pada hukum pidana tetapi berada dalam realitas masyarakat. ${ }^{6}$

Upaya penanggulangan kejahatan perlu ditempuh dengan pendekatan kebijakan, dalam arti ada ketepaduan antara politik kriminal dan politik sosial serta ada keterpaduan antara upaya penanggulangan kejahatan dengan penal dan non-penal. ${ }^{7}$ Mengenai kejahatan terorisme, Muladi berpendapat bahwa

5 F. Sugeng Istanto dalam Abdul Latif dan Hasbi Ali, Politik Hukum, Sinar Grafika, Jakarta, 2010, Hlm. 6

6 G. Peter Hoefnagels, The Other Side of Criminology, An Inversion of the Concept of Crime, Kluwer Deventer, Holland, 1972, Hlm. 47

${ }^{7}$ Muladi dan Barda Nawawi Arief, Bunga Rampai Kebijakan Hukum Pidana, Citra Aditya Bakti, Bandung, 2005, Hlm. 3 terorisme merupakan kejahatan luar biasa yang membutuhkan penanganan dengan mendayagunakan cara-cara luar biasa karena berbagai hal: ${ }^{8}$

1. Terorisme merupakan perbuatan yang menciptakan bahaya terbesar terhadap hak asasi manusia. Dalam hal ini hak asasi manusia untuk hidup dan hak asasi untuk bebas dari rasa takut.

2. Target terorisme bersifat random atau indiscriminate yang cenderung mengorbankan orang-orang tidak bersalah.

3. Kemungkinan digunakannya senjatasenjata pemusnah massal dengan memanfaatkan teknologi modern.

4. Kecenderungan terjadinya sinergi negatif antar organisasi terorisme nasional dengan organisasi internasional.

5. Kemungkinan kerjasama antara organisasi teroris dengan kejahatan yang terorganisasi baik yang bersifat nasional maupun transnasional.

6. Dapat membahayakan perdamaian dan keamanan internasional.

8 Muladi, Penanggulangan Terorisme Sebagai Tindak Pidana Khusus, bahan seminar Pengamanan Terorisme sebagai Tindak Pidana Khusus, Jakarta, 28 Januari 2004 


\section{Bagan 1.1 Motif Aksi Terorisme Di}

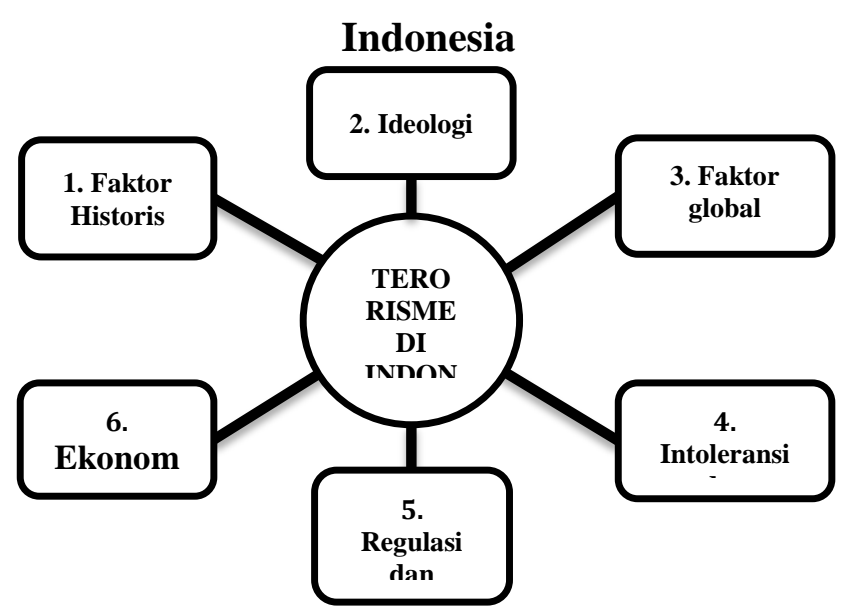

Motivasi seseorang untuk menjadi teroris sangatlah beragam, bahkan setiap individu teroris memiliki alasannya tersendiri. Menurut Levin, motivasi dan dampaknya yang luas ini merupakan karakteristik pembeda secara sederhana antara kejahatan teroris dengan kejahatan lainnya. ${ }^{9}$

Pembaharuan hukum pidana, terutama hukum pidana khusus terorisme yang responsif sebagai instrument hukum yang mampu merespon aspirasi sosial dalam penanggulangan kejahatan terorisme di Indonesia. Oleh karenanya diperlukan hubungan hukum dengan politik sebagai "legal and political aspirations and blandingof power", karena tipe hukum yang represif hanya memandang sebagai "law subordinated of power politics". Selain itu adalah upaya mengesampingkan

\footnotetext{
${ }^{9}$ Jack Levin, The Roots of Terrorism Domestic Terrorism, Chelsea House, New York, 2006, Hlm. 6
}

ego sektoral kelembagaan demi tercapainya tujuan bersama dalam penanggulangan terorisme di Indonesia. ${ }^{10}$

Berdasarkan hal tersebut diatas, maka penulis dapat membuat identifikasi masalah dalam pembahasan ini yaitu:

1. Bagaimana kebijakan formulasi peran Tentara Nasional Indonesia dalam pemberantasan terorisme dalam upaya menjaga kedaulatan Negara Kesatuan Republik Indonesia ditinjau dari perspektif pembaharuan hukum pidana?

2. Bagaimana implementasi peran Tentara Nasional Indonesia dalam pemberantasan terorisme dalam upaya menjaga kedaulatan Negara Kesatuan Republik Indonesia ditinjau dari perspektif pembaharuan hukum pidana?

3. Bagaimana peran Tentara Nasional Indonesia dalam pemberantasan terorisme dimasa yang akan datang dalam upaya menjaga kedaulatan Negara Kesatuan Republik Indonesia ditinjau dari perspektif pembaharuan hukum pidana?

\section{B. HASIL DAN PEMBAHASAN}

10 Adjat Sudradjat, Kebijakan Hukum Pidana Dalam Penanggulangan Tindak Pidana Terorisme Di Indonesia, CV. Murni Baru, Bandung, 2014, Hlm. 126 
1. Kebijakan Formulasi Peran

Tentara Nasional ndonesia

Dalam

Pemberantasan

Terorisme Dalam Upaya

Menjaga Kedaulatan Negara

Kesatuan Republik Indonesia

Ditinjau Dari Perspektif

\section{Pembaharuan Hukum Pidana}

Penggunaan hukum pidana dalam mengatur masyarakat (lewat peraturan perundang-undangan) pada hakekatnya merupakan bagian dari suatu langkah kebijakan (policy). Operasionalisasi kebijakan hukum pidana dengan sarana penal (pidana) dapat dilakukan melalui proses yang terdiri atas tiga tahap, yakni : ${ }^{11}$ Tahap formulasi (kebijakan legislatif), Tahap aplikasi (kebijakan yudikatif/yudisial), Tahap eksekusi (kebijakan eksekutif/administratif). Kriminalisasi dan penaliasi menjadi masalah sentral yang untuk penanganannya diperlukan pendekatan yang berorientasi pada kebijakan (policy oriented approach). Kriminalisasi (criminalisation) mencakup lingkup perbuatan melawan hukum (actus reus), pertanggungjawaban pidana (mens rea) maupun sanksi yang dapat dijatuhkan

\footnotetext{
${ }^{11}$ Aloysius Wisnubroto, Kebijakan Hukum Pidana dalam Penanggulangan Penyalahgunaan Komputer, Universitas Atmajaya ,Yogyakarta, 1999, Hlm.12
}

baik berupa pidana (punishment) maupun tindakan (treatment). Kriminalisasi harus dilakukan secara hati-hati, jangan sampai menimbulkan kesan represif yang melanggar prinsip ultimum remedium (ultima ratio principle) dan menjadi bumerang dalam kehidupan sosial berupa kriminalisasi yang berlebihan (overcriminalisation), yang justru mengurangi wibawa hukum. Kriminalisasi dalam hukum pidana materiil akan diikuti pula oleh langkah-langkah pragmatis dalam hukum pidana formil untuk kepentingan penyidikan dan penuntutan. ${ }^{12}$ Indonesia sebagai negara hukum (rechtstaat), memiliki kewajiban untuk melindungi harkat dan martabat manusia. ${ }^{13}$ Mekanisme penanganan aksi terorisme berdasarkan Undang-Undang No. 15 Tahun 2003 tentang Pemberantasan Tindak Pidana Terorisme dapat dilihat dalam tabel di bawah ini: Tabel 2.1 Mekanisme Penanganan Aksi Terorisme Berdasarkan UU No. 15 Tahun 2003 Tentang

\footnotetext{
12 Muladi, Kebijakan Kriminal terhadap Cybercrime, Majalah Media Hukum Vol. 1 No. 3 tanggal 22 Agustus 2003, Hlm. 1-2

${ }^{13}$ Abdul Wahid, Sunardi, dan Muhammad Imam Sidik, Kejahatan Terorisme Perspektif Agama, Hak Asasi Manusia dan Hukum, Refika Aditama, Bandung, 2004, Hlm. 66
} 


\section{Bagan 2.1 Pemberantasan Tindak Pidana Terorisme}

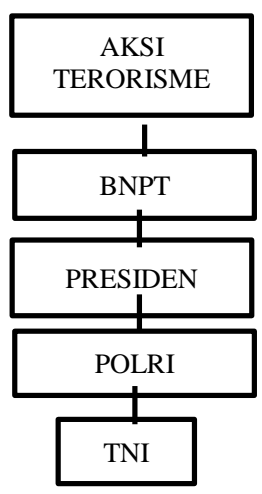

Tabel 2.1 ini menunjukkan TNI bersifat perbantuan ke Polri. UU No. 15 Tahun 2003 Penetapan atas Perpu No. 1 Tahun 2002 Tentang Pemberantasan Tindak Pidana Terorisme. Dalam UU No. 15 Tahun 2003 tidak ada 1 (satu) pasal pun yang mengatur perbantuan TNI kepada Polri atau pelibatan TNI dalam pemberantasan aksi terorisme. Jadi, perbantuan TNI terhadap Polri dalam pemberantasan aksi terorisme menunggu permintaan dari Polri dan atas keputusan kebijakan politik negara dalam hal ini Presiden. Secara empiris, sebenarnya selama ini TNI sudah dilibatkan untuk membantu kepolisian di dalam menghadapi ancaman dalam negeri contohnya, perbantuan TNI pada Polri pada kasus KBB di Papua, Operasi Tinombala Poso, Sulawesi Tengah Pegunungan Bosagong yang menewaskan gembong terorisme Santoso, kasus aksi terorisme Mapoltabes Surabaya di 3 (tiga) gereja di Surabaya, konflik Ambon Polri juga meminta bantuan TNI untuk ikut serta memberantas aksi terorisme.

Atas permohonan uji materiil UU No. 16/2003 terhadap Pasal 28 I ayat (1) UUD yang diajukan oleh Masykur Abdul Kadir, Mahkamah Kostitusi dalam putusannya tanggal 23 Juli 2004 No. 013/PUU-I/2003 telah menyatakan:

1. Mengabulkan permohonan pemohon untuk pengujian UU No. 16/2003terhadap UUD Negara 1945;

2. Bahwa UU No. 16/2003 bertentangan dengan UUD Negara 1945;

3. Bahwa UU No. 16/2003 tidak mempunyai kekuatan hukum mengikat;

Bahwa dari putusan MK tersebut dapat ditarik suatu temuan hukum, yaitu:

1. Penyimpangan dari asas nonretroaktif diperkenankan sepanjang untuk keperluan menegakkan keadilan bagi pelaku kejahatankejahatan HAM berat yang termasuk kategori kejahatan yang luar biasa (extra ordinary crime) dan tidak cukup dengan melalui hukum pidana biasa. 
2. Muatan kejahatan dalam peristiwa Bom Bali bukanlah termasuk kejahatan HAM berat, yang masih dapat ditanggulangi melalui hukum pidana konvensional.

3. Bahwa kriteria untuk dapat mengecualikan asas non-retroaktif yang digunakan MK adalah berupa kriteria mengenai objek muatan kejahatan dari penyimpangan, yang akan lebih baik dan sempurna apabila ditambah/disempurnakan dengan syarat utility dan keseimbangan, sehingga rumusnya ialah penyimpangan dari asas nonretroaktif hanya mungkin dilakukan apabila hukum pidana yang telah ada tidak dapat digunakan untuk melakukan penegakan hukum terhadap pembuat atau pembuatpembuat suatu peristiwa yang mengandung muatan kejahatan HAM berat, atau dalam hal ada hukum pidana yang dapat digunakan akan tetapi beban pertanggungjawaban pidananya tidak sebanding dengan beban pertanggungjawaban pidana menurut hukum pidana yang hendak diberlakukan surut.

4. Bahwa dengan terbitnya putusan MK No. 013/PUU-I/2003, maka sejak itu: a. Perlakuan hukum terhadap para pembuat atau yang terlibat lainnya pada peristiwa Bom Bali yang belum diputus pengadilan dengan putusan yang tetap, tidak dapat diberlakukan UU No. 15/2003.

b. Putusan MK No. 013/PUU-I/2003 tidak mengandung makna hukum dan pengaruh hukum apapun terhadap pembuat atau yang terlibat lainnya pada peristiwa Bom Bali yang telah diputus pengadilan dengan putusan yang tetap.

c. Putusan MK No. 013/PUU-I/2003 hanya mempunyai pengaruh dan berlaku terhadap para pembuat dan atau yang terlibat lainnya dalam peristiwa Bom Bali yang belum ada perlakuan hukum terhadapnya atau telah ada perlakuan hukum akan tetapi belum diputus oleh pengadilan dengan putusan yang mempunyai kekuatan hukum tetap.

d. Putusan MK No. 13/PUU-I/2003 bukan novum yang dapat digunakan sebagai dasar pengajuan upaya PK bagi 
terpidana dalam perisitiwa Bom Bali. $^{14}$

e. Di samping itu, sebagaimana lahirnya Undang-Undang Nomor 15 Tahun 2003, maka lahir pula Undang-Undang Nomor 16 Tahun 2003 Tentang Penetapan Peraturan Pemerintah Pengganti Undang-Undang Nomor 2 Tahun 2002 Tentang Pemberlakuan Peraturan Pemerintah Pengganti Undang-Undang No. 1 Tahun 2002 Tentang Pemberantasan Tindak Pidana Terorisme, pada peristiwa peledakan bom di Bali Tanggal 12 Oktober 2002 menjadi Undang-Undang. Ada beberapa hal yang menjadi pertimbangan hukum lahirnya Undang-Undang Nomor 16 Tahun 2003 ini, yaitu: Pertama, bahwa peristiwa pemboman di Bali pada tanggal 2 Oktober 2002 telah menimbulkan suasana teror atau rasa takut terhadap orang secara meluas serta mengakibatkan hilangnya nyawa dan kerugian harta benda. Kedua,bahwa peristiwa pembomam yang terjadi di Bali

\footnotetext{
${ }^{14}$ http://adamichazawi.blogspot.com/2009/09/implik
} asi-putusan-mk-no-13puu-i2003.html, telah membawa dampak yang luas terhadap kehidupan sosial, ekonomi, politik, dan hubungan Internasional serta mengancam perdamaian dan keamanan Internasional, sehingga PBB mengeluarkan resolusi Nomor 1438 (2002) dan resolusi Nomor 1371 (2001). Ketiga, bahwa untuk memberi landasan hukum yang kuat dalam mengambil langkahlangkah segera dalam rangka penyelidikan-penyelidikan dan penuntutan atas peristiwa pemboman yang terjadi di Bali, Presiden Republik Indonesia telah menetapkan PERPU No. 2 Tahun 2002 tentang Pemberlakuan Peraturan Pemerintah Pengganti Undang-Undang No. 1 Tahun 2002 tentang Pemberantasan Tindak Pidana terorisme, pada peristiwa peledakan bom di Bali tanggal 12 Oktober tahun 2002. ${ }^{15}$

f. Supaya dalam penanganan perkara terorisme tidak terganjal secara hukum oleh Pasal 1 ayat (1) KUHP, yang berbunyi

15 Ahmad Mukri Aji, Pemberantasan Tindak Pidana Terorisme Di Indonesia, Cita Hukum Vol 1 No. 1 Juni Universitas Islam Negeri Syarif Hidayatullah Jakarta, 2013, Hlm. 64 
"Nullum delictum nulla poena sine previa lage poenali”, yang terjemaahannya adalah "tidak ada suatu perbuatan dapat dihukum tanpa ada peraturan yang mengatur perbuatan tersebut sebelumnya", pemerintah menggunakan asas retroaktif dengan menerbitkan Peraturan Pemerintah Pengganti UndangUndang Nomor 2 Tahun 2002 Tentang Pemberlakuan Peraturan Pemerintah Pengganti UndangUndang Nomor 1 Tahun 2002 Tentang Pemberantasan Tindak Pidana Terorisme.

g. Pelibatan TNI telah disepakati dalam Undang-Undang No. 5 Tahun $2018 \quad$ tentang Pemberantasan Tindak Pidana Terorisme, yang dalam ayat 1 menyatakan, "tugas TNI dalam mengatasi aksi terorisme merupakan bagian dari operasi militer selain perang",ayat 2 menyatakan, "dalam mengatasi aksi terorisme sebagaimana dimaksud pada ayat (1) dilaksanakan sesuai dengan tugas pokok dan fungsi TNI". Sementara, pembuatan Perpres merupakan amanat ayat 3 yang menyatakan, "Ketentuan lebih lanjut mengenai pelaksanaan mengatasi aksi terorisme sebagaimana dimaksud pada ayat (1) diatur dengan Peraturan Presiden". Pasal pelibatan TNI sudah sesuai dengan UU TNI Nomor 34 Tahun 2004 Pasal 5 dan 6 tentang tugas dan fungsi TNI untuk menjaga keutuhan Negara Kesatuan Republik Indonesia (NKRI) dan Pasal 7 ayat 2 dan 3 tentang Operasi Militer Selain Perang (OMSP). ${ }^{16}$

h. Undang-Undang Nomor 5 Tahun 2018 ini telah mengamanatkan 8 (delapan) peraturan pelaksanaan yaitu 5 (lima) peraturan pemerintah, 2 (dua) Peraturan Presiden dan 1 (satu) Peraturan DPR RI. Salah satu Peraturan Pelaksanaan yang terkait dengan peran TNI dalam UU tersebut adalah Peraturan Presiden tentang mengatasi aksi terorisme. Pembentukan Perpres tersebut merupakan delegasi/ perintah dari Pasal 43I ayat (3), batas waktu

16 https://tirto.id/pasal-ruu-terorisme-tak-diubahtni-bisa-ikut-berantas-aksi-teror-cK5F, diakses pada tanggal 26 Januari 2019 
pembentukan Perpres 1 (satu) tahun sejak UU terorisme diundangkan (22 Juni 2018 s.d 22 Juni 2019) hal ini sesuai dengan ketentuan yang diatur di dalam Pasal 46B, Peraturan Presiden yang akan dibentuk terlebih dahulu harus dikonsultasikan dengan DPR RI.

i. Hal ini sesuai dengan Pasal 43I ayat (3), materi RPerpres mengacu pada UU terorisme, materi RPerpres sebaiknya lebih tajam dan lebih operasional, substansi RPerpres meliputi pencegahan, penindakan dan pemulihan (dirumuskan berdasarkan tugas dan fungsi TNI), materi lain mengatur mekanisme peran TNI, tataran kewenangan, kerjasama lembaga nasional dan Internasional, pendanaan. ${ }^{17}$

j. Peran TNI dalam mengatasi aksi terorisme mulai dari upaya pencegahan, penindakan dan pemulihan dilaksanakan secara bekerjasama dengan kementrian/lembaga terkait di bawah koordinasi badan yang

17 Edy Imran, Op.Cit., Hlm. 9 menyelenggarakan urusan di bidang penanggulangan terorisme/BNPT, sedangkan substansi lainnya yang akan diatur dalam RPerpres antara lain Bab I ketentuan Umum, Bab II pencegahan, penindakan dan pemulihan, Bab III mekanisme mengatasi aksi terorisme (cegah, tindak pulih), Bab IV tataran kewenangan (BNPT, MENHAN, PANGLIMA TNI), Bab V kerjasama antar lembaga nasional dan Internasional $\mathrm{Bab} \quad \mathrm{VI}$ pendanaan Bab VII penutup.

k. Pada penjelasan Pasal 43I dijelaskan bahwa tugas TNI dalam mengatasi aksi terorisme tersebut dilaksanakan menurut ketentuan yang telah diatur dalam Undang-Undang Nomor 34 Tahun 2004 tentang TNI dan UndangUndang Nomor 3 Tahun 2000 Tentang Pertahanan Negara. Selanjutnya penjelasan ayat (3) disebutkan bahwa dalam membentuk Peraturan Presiden dilakukan dengan berkonsultasi dengan Dewan Perwakilan Rakyat Republik Indonesia. Jadi, pelibatan TNI dalam mengatasi 
aksi terorisme tidak dapat dipungkiri lagi dan tidak dapat diperdebatkan lagi, karena sudah merupakan keputusan politik yang telah disepakati antara Pemerintah dan DPR, disamping itu tidak bisa di pungkiri pula bahwa TNI merupakan salah satu komponen yang dimiliki negara Republik Indonesia yang memiliki kemampuan dan sarana prasarana yang seharusnya dapat digunakan dalam penanggulangan aksi terorisme di Indonesia. ${ }^{18}$

\section{Implementasi Peran Tentara} Nasional Indonesia Dalam

\section{Pemberantasan} Terorisme

Dalam Upaya Menjaga

Kedaulatan Negara Kesatuan Republik Indonesia Ditinjau Dari Perspekti Pembaharuan Hukum

\section{Pidana}

Berkaitan dengan pelibatan TNI, menurut Abdul Fickar, pelibatan TNI dalam pemberantasan terorisme harus tetap berpedoman pada UU Nomor 34 Tahun 2004 tentang TNI khususnya Pasal 7, pelibatan TNI dalam pemberantasan terorisme merupakan sebuah hal yang

18 Hambali, Pelibatan TNI Dalam Pemberantasan Aksi Terorisme, Seminar, Universitas Indonesia. Hlm. 1 dimungkinkan bila terorisme dilihat sebagai sebuah tindakan yang mengancam keutuhan dan pertahanan negara. Namun demikian, pelibatan TNI dalam pemberantasan terorisme harus tetap mengedepankan profesionalitas Kepolisian Negara Republik Indonesia (Polri) dengan menghindari berbagai tindakan yang berpotensi melanggar hak asasi manusia (HAM). ${ }^{19}$ Terdapat 3 (tiga) konvensi Internasional mengenai pemberantasan tindak pidana terorisme yang dapat menjadi rujukan, diantaranya: ${ }^{20}$

1. Convention For the Prevention and Punishment of Terrorism, 1937 (Konvensi tentang Pencegahan dan Pemberantasan Terorisme);

2. International Convention For the Suppression of Terrorist Bombing 1997 (Konvensi Internasional tentang Pemberantasan Pengeboman oleh Terorisme) disahkan oleh Pemerintah Republik Indonesia dengan Undang-Undang Nomor 5 Tahun 2006 Tanggal 5 April 2006;

\footnotetext{
${ }^{19}$ https://www.cnnindonesia.com/nasional/2018052 7124708-32-301635/relevansi-dan-batasanperan-tni-dalam-uu-terorisme, diakses pada tanggal 26 Januari 2019

20 Komnas HAM, Laporan Tim Evaluasi Penanganan Tindak Pidana Terorisme di Indonesia, Jakarta, 2017
} 
3. International Convention For the Suppression of Financing of Terorism $1999 \quad$ (Konvensi International Tentang Pemberantasan Pendanaan untuk Kegiatan Terorisme).

Menurut konvensi tersebut tindak pidana terorisme bukan termasuk dalam kejahatan luar biasa (extra ordinary crime), akan tetapi termasuk kategori kejahatan serius, mengingat dampaknya yang mengguncang nurani umat manusia karena sifat kejamnya, besarnya jumlah korban, sifat tidak memilah-milahnya (indiscriminate), parahnya kerusakan harta milik, dan dampak psikologis jangka panjang yang telah di derita korban dan/atau orang lain yang menyaksikannya. ${ }^{21}$ UndangUndang Nomor 5 Tahun 2018 tentang Pemberantasan Tindak Pidana Terorisme terdapat nuansa penggunaan delik formil karena dalam rumusan dicantumkan secara tegas perihal larangan melakukan perbuatan tertentu, tanpa mengharuskan selesainya perbuatan tersebut. Dalam hubungannya dengan selesainya tindak pidana, jika

21 Enny Soeprapto, Amanat Yuridis Peraturan Perundang-Undangan dan Kebijakan Mengenai Penanganan Kejahatan Terorisme di Indonesia, Komnas HAM RI, 2016 perbuatan yang menjadi larangan itu selesai dilakukan, tindak pidana itu selesai pula, tanpa bergantung pada akibat yang timbul dari perbuatan dan/atau tidak mempersoalkan akibat dari tindakan tersebut. ${ }^{22}$

\section{Peran Tentara Nasional Indonsia}

Dalam Pemberantasan Terorisme

Dimasa Yang Akan Datang Dalam Upaya Menjaga Kedaulatan Negara Kesatuan Republik Indonesia Ditinjau Dari Perspektif Pembaharuan Hukum Pidana

Masuknya TNI dalam UU Anti terorisme ini untuk mengisi kekurangan Polri sebagai leading sector penanganan terorisme. Pelibatan juga sesuai dengan koridor wilayahnya. Perpres ini mengatur secara menyeluruh area mana saja yang TNI perlu turun, terutama yang menyangkut keamanan negara, maka TNI harus turun, kehadiran TNI sesuai dengan pasal 6 Undang-Undang nomor. 34 tahun 2004 tentang TNI yaitu meliputi pencegahan, penindakan dan pemulihan.

Sasaran yang ingin diwujudkan melalui Rancangan Peraturan Presiden ini yaitu sebagai landasan hukum bagi TNI

22 Adami Chazawi, Stelsel Pidana, Tindak Pidana, Teori-Teori Pemidanaan \& Batas Berlakunya Hukum Pidana, PT. Raja Grafindo Persada, Jakarta, 2010, Hlm.119 
dalam melaksanakan perintah UndangUndang untuk mengatasi aksi terorisme yang merupakan bagian dari tugas TNI dalam melaksanakan tugas operasi militer selain perang (OMSP). Selain itu, Perpres akan mengkategorikan spektrum ancaman sebagai indikator Koopsusgab TNI harus turun tangan memberantas terorisme atau tidak. Spektrum ancaman, ada low intensity, medium intensity dan high intensity.Jadi, penentuan dari medium ke high itu nantinya dipimpin Presiden beserta Dewan Keamanan Nasional yang anggotanya Menkopolhukam, Menhan, Mendagri, Kapolri, Kepala BIN dan Panglima TNI.

\section{Bagan 2.2 Konsep Penanganan Aksi}

Terorisme Dalam Perpres Pelibatan

TNI Dalam Pemberantasan Terorisme

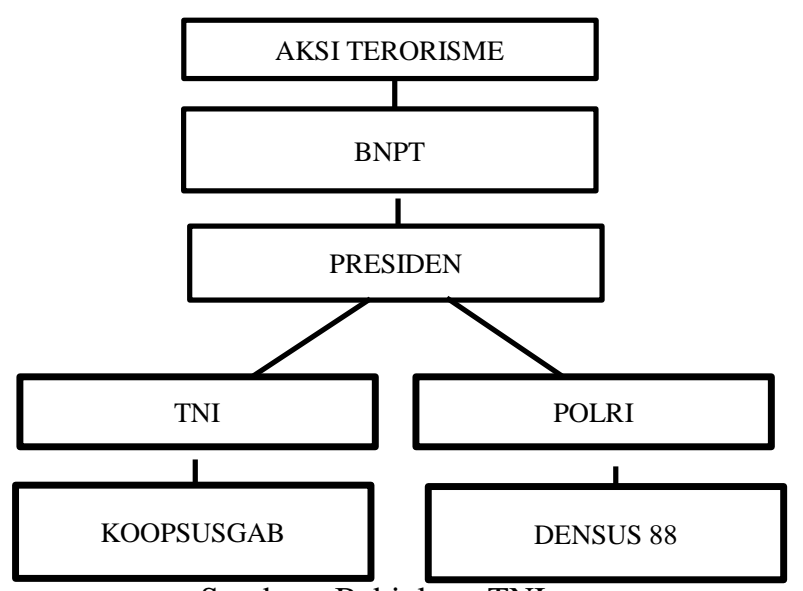

Sumber : Babinkum TNI

Tabel ini menunjukkan, dengan diundangkannya UU No. 5 Tahun 2018 tentang Pemberantasan Tindak Pidana
Terorisme, pelibatan TNI dalam pemberantasan aksi terorisme yang terdapat dalam Pasal 43I yang mendelegasikan atau memerintahkan kepada Presiden untuk membuat aturan pelaksanaan pelibatan TNI dalam pemberantasan aksi terorisme. Dengan demikian, pelibatan TNI dalam pemberantasan aksi terorisme tidak lagi bersifat perbantuan kepada Polri namun, sudah bergerak secara langsung atau mandiri berdasarkan Peraturan Presiden, dengan berbasis pada peristiwa yang meliputi tempat / lokasi peristiwa, target orang, skala atau level ancaman, kwalitas dan kwantitas daripada aksi terorisme. Pernyataan bahwa TNI tidak lagi bersifat perbantuan terhadap Polri telah dibahas dalam rapat internal pada tanggal 11 dan 12 Januari 2017 dalam Panja Pemerintahan pembahasan RUU terorisme.

Adapun substansi yang akan diatur dalam Rperpres tersebut meliputi tiga fungsi TNI yaitu pencegahan, penindakan dan pemulihan.Ketiga fungsi ini adalah sebagai implementasi dari Pasal 6 UU No. 34 Tahun 2004 tentang TNI. 


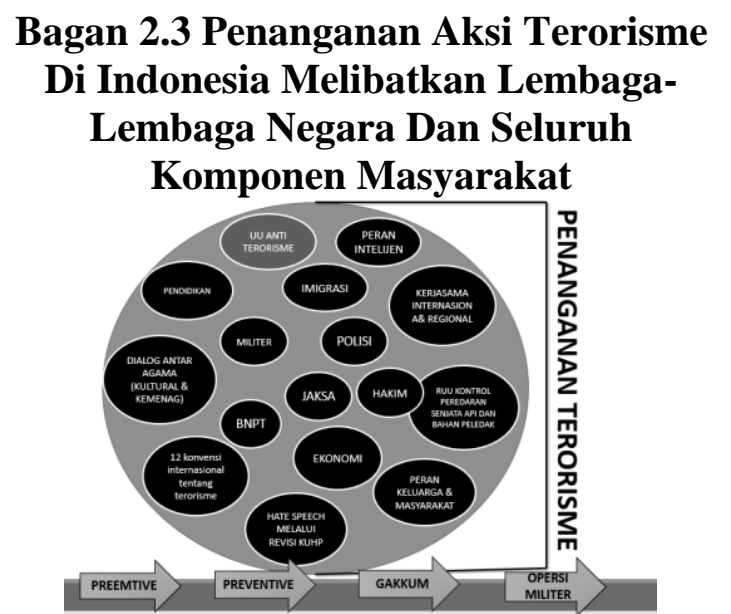

Sumber : Kontras 13 November 2018

\section{PENUTUP}

\section{Simpulan}

1. Kebijakan formulasi peran TNI dalam pemberantasan terorisme dalam upaya menjaga kedaulatan NKRI akan diatur Perpres sesuai amanat Pasal 34I UU No. 5 Tahun 2018 Tentang Pemberantasan Tindak Pidana Terorisme. Adapun isi Peraturan Presiden tersebut meliputi 3 (tiga) fungsi TNI, yaitu fungsi pencegahan, penindakan dan pemulihan. Ketiga fungsi tersebut adalah sebagai implementasi dari Pasal 6 Undang-Undang No. 34 Tahun 2004 tentang Tentara Nasional Indonesia. Kebijakan formulasi tersebut dilaksanakan melalui kerjasama dengan Kementrian atau lembaga-lembaga terkait di bawah koordinasi badan yang menyelenggarakan urusan dibidang penanggulangan terorisme, yaitu BNPT.

2. Implementasi peran Tentara Nasional Indonesia dalam pemberantasan tindak pidana terorisme dalam upaya menjaga kedaulatan NKRI secara eksplisit telah diatur dalam beberapa peraturan perundang-undangan. seperti UU No. 3 Tahun 2002 tentang Pertahanan Negara, UU No. 34 Tahun 2004 tentang TNI, dan UU No. 5 Tahun 2018 tentang Pemberantasan Tindak Pidana Terorisme. Namun, penerapan UU yang berkaitan dengan pelibatan TNI dalam pemberantasan aksi terorisme sebagaimana amanat Pasal 34I Undang-Undang Nomor 5 Tahun 2018 tentang Pemberantasan Tindak Pidana Terorisme, belum dapat diimplementasikan secara konkrit dilapangan karena terkendala oleh pembentukan Perpres sebagai aturan pelaksanaan pelibatan TNI yang belum rampung sampai saat ini, sehingga pelibatan TNI dalam pemberantasan aksi terorisme masih bersifat perbantuan terhadap institusi Polri melalui kebijakan politik negara. 
3. Peran TNI dimasa yang akan datang dalam pemberantasan aksi terorisme dalam upaya menjaga kedaulatan NKRI ditinjau dari perspektif pembaharuan hukum pidana berorientasi pada kebijakan dan sekaligus pendekatan yang berorientasi pada nilai, namun tetap harus mengedepankan prinsip law enforcement. Orientasi pada kebijakan dapat dilihat pada pembentukan Undang-Undang Nomor 5 Tahun 2018 tentang Pemberantasan Tindak Pidana Terorisme, dan rencana penerbitan Perpres yang mengatur pelibatan TNI dalam pemberantasan terorisme. Orientasi pada nilai, adalah bahwa pelibatan TNI ini didasarkan pada pertimbangan, bahwa tindak pidana terorisme yang selama ini terjadi di Indonesia merupakan kejahatan yang serius yang membahayakan ideologi negara, keamanan negara, kedaulatan negara, nilai, kemanusiaan dan berbagai aspek kehidupan bermasyarakat, berbangsa dan bernegara serta bersifat lintas negara, terorganisasi dan mempunyai jaringan yang luas serta memiliki tujuan tertentu.

\section{Saran}

1. Penanggulangan terorisme bukan hanya semata-mata penanganan perkara dalam penegakan hukum, tetapi harus dilihat secara menyeluruh akar permasalahannya. Perlunya Pemerintah dan DPR merumuskan kebijakan penanganan terorisme secara komprehensif dan lebih baik dengan cara membentuk peraturan perundangundangan yang khusus tentang peran TNI dalam pemberantasan aksi terorisme agar tidak terjadi tumpang tindih peran dan kewenangan antara TNI dan Polri.

2. Kepada Presiden RI supaya segera merampungkan Perpres yang menjadi mandat dari UU No. 5 Tahun 2018 tentang Pemberantasan Tindak Pidana Terorisme sebagai aturan pelaksana TNI dalam pemberantasan aksi terorisme sebagaimana tercantum dalam Pasal 43I.

3. Di masa depan Pemerintah dan DPR perlu membentuk badan pelaksana operasi gabungan untuk mengatasi aksi terorisme yang beranggotakan dari institusi-institusi lintas sektoral untuk mewujudkan sinkronisasi satuan-satuan operasional (pemukul) dalam memberantas aksi terorisme, agar 
terjadi sinergitas dan kekompakan dalam menangani aksi terorisme untuk mewujudkan keamanan nasional.

\section{DAFTAR PUSTAKA}

Abdul Wahid, Sunardi, dan Muhammad Imam Sidik, Kejahatan Terorisme Perspektif Agama, Hak Asasi Manusia dan Hukum, Refika Aditama, Bandung, 2004

Adami Chazawi, Stelsel Pidana, Tindak Pidana, Teori-Teori Pemidanaan \& Batas Berlakunya Hukum Pidana, PT. Raja Grafindo Persada, Jakarta, 2010

Adjat Sudradjat, Kebijakan Hukum Pidana Dalam Penanggulangan Tindak Pidana Terorisme Di Indonesia, CV. Murni Baru, Bandung, 2014

Ahmad Mukri Aji, Pemberantasan Tindak Pidana Terorisme Di Indonesia, Cita Hukum Vol 1 No. 1 Juni Universitas Islam Negeri Syarif Hidayatullah Jakarta, 2013

Aloysius Wisnubroto, Kebijakan Hukum Pidana dalam Penanggulangan Penyalahgunaan Komputer, Universitas Atmajaya, Yogyakarta, 1999

Edy Imran, Pelibatan TNI Dalam Pemberantasan Aksi Terorisme, Seminar, Universitas Indonesia, 2018

Enny Soeprapto, Amanat Yuridis Peraturan Perundang-Undangan dan Kebijakan Mengenai Penanganan Kejahatan Terorisme di Indonesia, Komnas HAM RI, 2016

F. Sugeng Istanto dalam Abdul Latif dan Hasbi Ali, Politik Hukum, Sinar Grafika, Jakarta, 2010

G. Peter Hoefnagels, The Other Side of Criminology, An Inversion of the Concept of Crime, Kluwer Deventer, Holland, 1972
Hambali, Pelibatan TNI Dalam Pemberantasan Aksi Terorisme, Seminar, Universitas Indonesia.

http://adamichazawi.blogspot.com/2009/09 limplikasi-putusan-mk-no-13puui2003.html, 2019

https://tirto.id/pasal-ruu-terorisme-takdiubah-tni-bisa-ikut-berantas-aksiteror-cK5F, 2019

https://www.cnnindonesia.com/nasional/20 180527124708-32-301635/relevansidan-batasan-peran-tni-dalam-uuterorisme, 2019

Jack Levin, The Roots of Terrorism Domestic Terrorism, Chelsea House, New York, 2006

Juniarso Ridwan, Achmad Sodik Sudrajat, Hukum Administrasi Negara Dan Kebijakan Layanan Publik, Nuansa Cendekia, Bandung, 2014

Komnas HAM, Laporan Tim Evaluasi Penanganan Tindak Pidana Terorisme di Indonesia, Jakarta, 2017

Mahfud M.D. (1), Perdebatan Hukum Tata Negara Pasca Amandemen Konstitusi, LP3ES, Jakarta, 2007

Muladi dan Barda Nawawi Arief, Bunga Rampai Kebijakan Hukum Pidana, Citra Aditya Bakti, Bandung, 2005

Muladi, Kebijakan Kriminal terhadap Cybercrime, Majalah Media Hukum Vol. 1 No. 3 tanggal 22 Agustus 2003

Muladi, Penanggulangan Terorisme Sebagai Tindak Pidana Khusus, bahan seminar Pengamanan Terorisme sebagai Tindak Pidana Khusus, Jakarta, 2004

Yusril Ihza Mahendra, Dinamika Tata Negara Indonesia: Konfilasi Aktual Masalah Konstitusi Dewan Perwakilan dan Sistem Kepartaian, Gema Insani, Jakarta, 1996 